\title{
Turner syndrome masquerading as normal early puberty
}

\author{
Yong Hee Hong, MD, PhD, \\ Young Lim Shin, MD, PhD \\ Department of Pediatrics, \\ Soonchunhyang University Bucheon \\ Hospital, Soonchunhyang University \\ College of Medicine, Bucheon, Korea
}

Approximately $50 \%$ of patients with Turner syndrome (TS) have complete loss of one $\mathrm{X}$ chromosome, whereas the rest of the patients with TS display mosaicism or structural abnormalities of the $X$ chromosome. Most well-known common features are short stature and gonadal failure. Approximately one third of girls with TS may enter spontaneous puberty, but only half those completed with menarche. However, some atypical features of TS have been described. Many studies have been conducted to verify and delineate proposed loci for genes pertaining to the TS phenotype, and correlations between karyotype and phenotype. A few rare cases of precocious puberty with TS have been described. Here we describe a case of TS with the Xp22.1 deletion presenting with short final stature, early normal onset of spontaneous puberty, and Graves' disease, without short stature during puberty.

Keywords: Puberty, Graves disease, Turner syndrome

\section{Introduction}

Turner syndrome (TS) is the most common chromosomal aneuploidy that affects 1 in every 2,000 girls, and is characterized by short stature and gonadal dysgenesis in females who lack all or part of one $\mathrm{X}$ chromosome $\mathrm{e}^{1)}$. Approximately $50 \%$ of patients with TS have complete loss of one $\mathrm{X}$ chromosome, whereas the rest of patients with TS display mosaicism or structural abnormalities of the $\mathrm{X}$ chromosome, for example, 46, X, i Xq), 46, X, $\operatorname{del}(\mathrm{X}), 46, \mathrm{X}, \mathrm{r}(\mathrm{X})$, etc. ${ }^{2}$. Like complete monosomy $\mathrm{X}$, partial deletions of either the short arm or long arm can cause features of TS. Many studies have been conducted to verify and delineate the proposed loci for genes pertaining to the TS phenotype. Some studies have indicated that the genes for physical and cognitive features lie on $\mathrm{Xp}$, whereas genes for ovarian function are present on both $\mathrm{Xp}$ and $\mathrm{Xq}^{3-5}$. The correlation of thyroid autoimmunity with the type of karyotype abnormality and loci of gene is not well-described with conflicting results ${ }^{6-9)}$. Approximately one third of girls with TS may enter spontaneous puberty, but only half those completed with menarche ${ }^{10)}$. The prevalence of spontaneous puberty is higher in patients with mosaic TS. And there were a few rare cases ${ }^{10-14)}$ about TS with precocious puberty.

The authors report a 17-year-old TS variant patient with early normal puberty and Graves disease, who had no clinical features of TS during puberty.

Address for correspondence:

Young Lim Shin, MD, PhD

Department of Pediatrics,

Soonchunhyang University

Bucheon Hospital, Soonchunhyang

University College of Medicine, 170

Jomaru-ro, Wonmi-gu, Bucheon

420-767, Korea

Tel: +82-32-621-6723

Fax: +82-32-621-6950

E-mail:ylshin@schmc.ac.kr

Received: 11 June, 2014

Revised: 13 August, 2014

Accepted: 7 September, 2014

\section{Case report}

A 17-year-old girl visited the hospital with the chief compliant of goiter with acute onset. She was born via spontaneous vaginal delivery at 37 -week gestation, weighing $2.6 \mathrm{~kg}$. She was the second child of unrelated healthy parents. Her father was $171 \mathrm{~cm}$ tall and her mother was $158 \mathrm{~cm}$ tall. Midparental height was $158 \mathrm{~cm}$.

She had visited our clinic for growth evaluation at 11 years 10 months of age, when her height was $141.2 \mathrm{~cm}$ (10th-25th percentile) and her weight was $39.7 \mathrm{~kg}$ (50th percentile). 
Tanner stage was breast 4 and pubic hair 4 . Her bone age was approximately 13 years and her height for bone age was $<3 \mathrm{rd}$ percentile. Menstruation had been started at 10 years 9 months of age. According to her school record, she was short before pubertal onset, but her height and weight were relatively normal during puberty (Fig. 1). So, idiopathic short stature and early normal puberty were diagnosed at 11 years 10 months of age.

At the age of 17 years, goiter developed abruptly, and the patient visited the hospital again. She was short in stature and of normal weight, measuring $144.7 \mathrm{~cm}$ ( $<3$ rd percentile) and weighing $44 \mathrm{~kg}$ ( $3 \mathrm{rd}-5$ th percentile). She showed no signs of TS, such as webbed neck, short neck, cubitus valgus, high arched palate, and shield chest deformity, except for short stature. Her menstrual cycle was regular. Tanner stage was breast 5 and pubic hair 5. She had normal intelligence and high grades in school.

The laboratory profiles demonstrated normal complete blood count, chemistry panel, and electrolytes. The thyroid function test showed: thyroid stimulating hormone (TSH), $0.01 \mathrm{mIU} / \mathrm{L}$ (reference, 0.25-4.0 mIU/L); free thyroxine, $7.3 \mathrm{ng} / \mathrm{dL}$ (reference, 0.7-2.0 ng/dL); triiodothyronine, $680 \mathrm{ng} / \mathrm{dL}$ (reference, 60-190 $\mathrm{ng} / \mathrm{dL}$ ), thyroglobuin antibody, $7.06 \mathrm{U} / \mathrm{mL}$ (reference, $0-0.3 \mathrm{U} /$ $\mathrm{mL}$ ); thyroid stimulating immunoglobulin, $22.7 \%$ (reference, 0\%-15\%); microsomal antibody, $1.45 \mathrm{U} / \mathrm{mL}$ (reference, $0-0.3$ $\mathrm{U} / \mathrm{mL}$ ), suggesting Graves disease. On thyroid ultrasonography, enlargement of both thyroid glands with increased vascularity was observed. A Technetium-99m thyroid scan showed diffuse, enlarged thyroid glands with markedly increased uptake. Other results were as follows: luteinizing hormone $(\mathrm{LH}), 14.65 \mathrm{mIU} /$ $\mathrm{mL}$ (reference: follicular phase, 0.6-6.2 $\mathrm{mIU} / \mathrm{mL}$; luteal phase, 0-6.0 mIU/mL); follicle stimulating hormone $(\mathrm{FSH}), 7.78 \mathrm{mIU} /$ $\mathrm{mL}$ (reference: follicular phase, $3.3-8.8 \mathrm{mIU} / \mathrm{mL}$; luteal phase, 1.6-8.7 mIU/mL); and estradiol, $156.99 \mathrm{pg} / \mathrm{mL}$ (reference: follicular phase, $60-200 \mathrm{pg} / \mathrm{mL}$; luteal phase, $60-260 \mathrm{pg} / \mathrm{mL}$ ), without evidence of ovarian failure. Because the final height was below the 3 rd percentile with coexisting thyroid dysfunction and autoimmunity, chromosome analysis was performed. The karyotype was 46,X,del(X)(p22.1), one of the form of TS (Fig. 2 ). Methimazole was prescribed for the patient and a regular thyroid function test was performed.

\section{Discussion}

Loss of interstitial or terminal long-arm material of the $\mathrm{X}$ chromosome $(\mathrm{Xq})$ can result in short stature and primary or secondary ovarian failure ${ }^{15)}$. However, absence of the long arm of the $\mathrm{X}$ chromosome with normal stature suggests that the presence of the short arm of the X chromosome maintains the stature of the affected patient ${ }^{1)}$. Deletion involving the long arm of the $\mathrm{X}$ chromosome

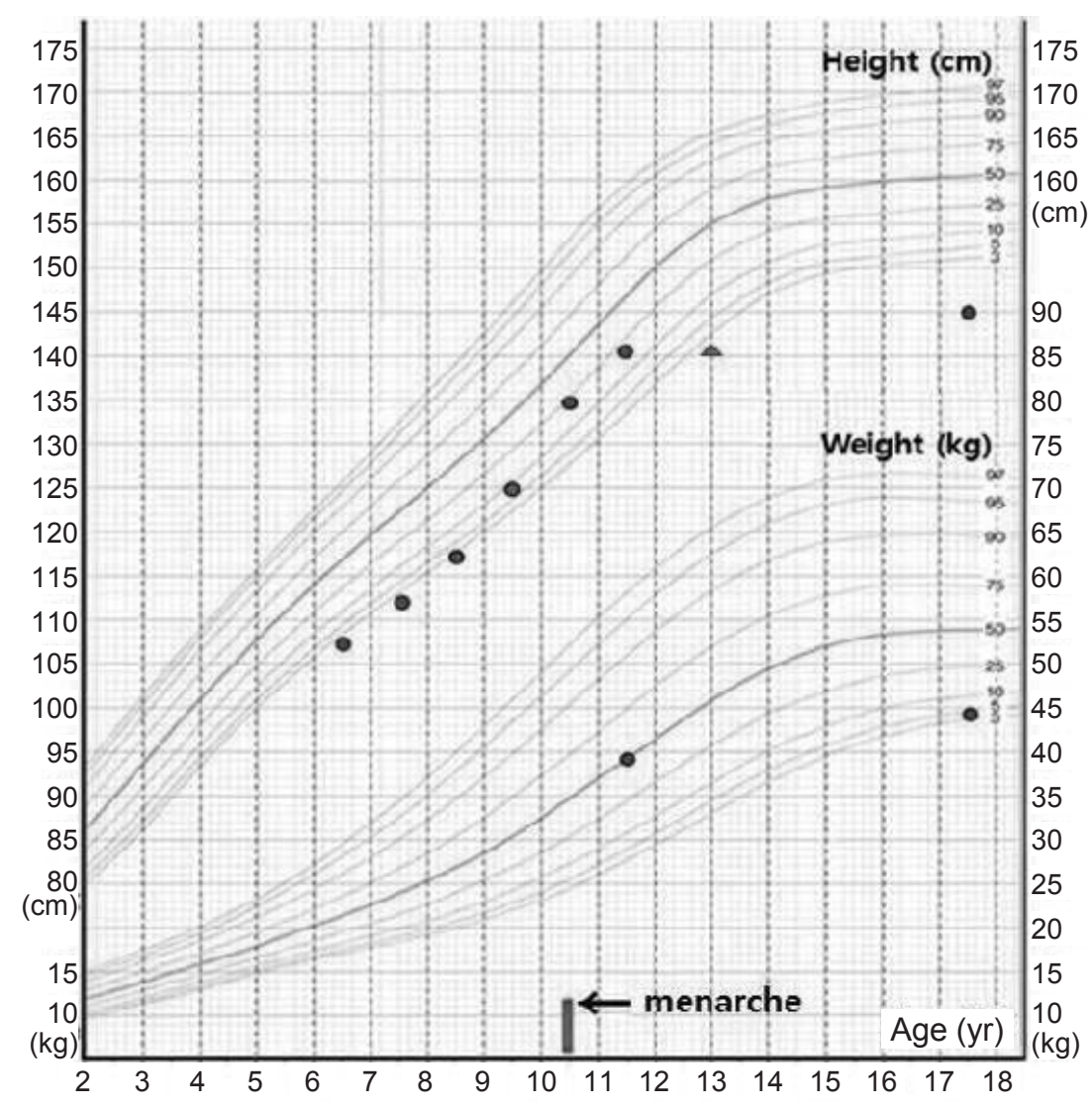

Fig. 1. Growth chart of our patient ( $\Delta$ : height for bone age). 


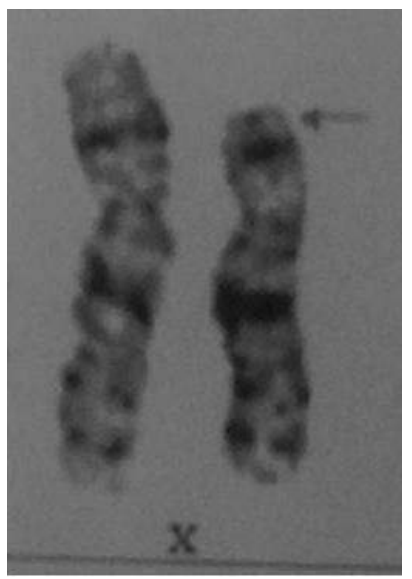

Fig. 2. The karyotype shows $46, X$, del(X)(p22.1).

generally results in ovarian failure if the proposed critical region Xq13-q26 is involved ${ }^{1)}$. Deletion of the whole short arm of the $\mathrm{X}$ chromosome (Xp) in females is associated with short stature, ovarian failure, and the classic stigmata of TS. The prevalence of an Xp deletion among patients with TS is $2 \%{ }^{16)}$. Patients with terminal Xp deletion have short stature and may have some somatic traits of TS; gonadal function is generally preserved ${ }^{16)}$. Women with more distal deletions [del $(\mathrm{X})(\mathrm{p} 21.1$ to $\mathrm{p} 22.1$ or $\mathrm{p} 22.2]$ menstruate more often, but many are infertile or have secondary amenorrhea ${ }^{17)}$. Thus, Xp [X(pter->p21] clearly plays a role in ovarian development. Therefore, we should perform follow-up regarding fertility or occurrence of secondary amenorrhea even in a patient with distal Xp deletion, although our patient had normal puberty and menstruation in adolescence. The Xp22.3-Xp22.12 region is located at the Xp terminus and includes the SHOX gene. The SHOX gene is located at the very tip of the short arm of both sex chromosomes, inside the telomeric portion of pseudoautosomal region 1 , containing genes that escape $\mathrm{X}$ inactivation. The $\mathrm{X}$-linked zinc finger protein $(Z f x)$ is also located at Xp22.1-21.3, and is a candidate gene for short stature and ovarian failure ${ }^{17)}$. Most TS patients with Xp deletion have short stature, considering statural determinant ${ }^{17)}$. However, this patient's height was in the normal range (10th-25th percentile) from 9 years to 12 years and she experienced short stature after puberty. The exact cause of normal height during the period is unclear, and maybe because of the effect of intact Xq chromosome and early normal puberty, respectively. There are only six cases ${ }^{10-14)}$ about central precocious puberty in patient with TS have been reported. Five of them showing mosaic TS and one of them showing structural abnormality of one X chromosome like our patient. The mechanism is unclear, and may be the result of abnormalities in the hypothalamic feedback system with increased levels of gonadotropins, FSH surge before ovarian failure, or elevated levels of TSH by interaction between TSH and the human FSH receptor. All had normal height according to standard growth curve when diagnosed as TS, like this case. When precocious puberty is combined with TS or if midparental height is tall, the patient may have normal height and the diagnosis may be delayed ${ }^{12)}$. More studies are needed regarding the correlation between TS and central precocious puberty. With regard to thyroid autoimmunity, correlation with karyotype and phenotype shows variable results ${ }^{7}$. In some of the studies, especially in girls with isochromosome Xq, levels of thyroid autoantibody are the highest ${ }^{7,8)}$, but in others ${ }^{9)}$, the results did not reach statistical significance.

In conclusion, we experienced a case of TS with Xp22.1 deletion presenting with short final stature, early normal puberty, and Graves disease, without short stature during puberty. We suggest that even though a patient's puberty is normal, when the final height is short and autoimmune thyroid disease is accompanied, chromosome analysis for TS should be considered. Further research about determinant factors and genes on the $\mathrm{X}$ chromosome in growth, ovarian function, and autoimmunity is needed. Additionally, screening karyotypically normal individuals with TS features for mutations in candidate genes is necessary.

\section{Conflict of interest}

No potential conflict of interest relevant to this article was reported.

\section{References}

1. Moka R, Sreelakshmi K, Gopinath PM, Satyamoorthy K. Cytogenetic evaluation of patients with clinical spectrum of Turner syndrome. J Hum Reprod Sci 2013;6:129-32.

2. Zinn AR, Ross JL. Molecular analysis of genes on Xp controlling Turner syndrome and premature ovarian failure (POF). Semin Reprod Med 2001;19:141-6.

3. Ferguson-Smith MA. Karyotype-phenotype correlations in gonadal dysgenesis and their bearing on the pathogenesis of malformations. J Med Genet 1965;2:142-55.

4. Ogata T, Matsuo N. Turner syndrome and female sex chromosome aberrations: deduction of the principal factors involved in the development of clinical features. Hum Genet 1995;95:607-29.

5. Ross JL, Roeltgen D, Kushner H, Wei F, Zinn AR. The Turner syndrome-associated neurocognitive phenotype maps to distal Xp. Am J Hum Genet 2000;67:672-81. 
6. Gawlik A, Gawlik T, Januszek-Trzciakowska A, Patel H, Malecka-Tendera E. Incidence and dynamics of thyroid dysfunction and thyroid autoimmunity in girls with Turner's syndrome: a long-term follow-up study. Horm Res Paediatr 2011;76:314-20.

7. Livadas S, Xekouki P, Fouka F, Kanaka-Gantenbein C, Kaloumenou I, Mavrou A, et al. Prevalence of thyroid dysfunction in Turner's syndrome: a long-term follow-up study and brief literature review. Thyroid 2005;15:1061-6.

8. Elsheikh M, Wass JA, Conway GS. Autoimmune thyroid syndrome in women with Turner's syndrome: the association with karyotype. Clin Endocrinol (Oxf) 2001;55:223-6.

9. El-Mansoury M, Bryman I, Berntorp K, Hanson C, Wilhelmsen L, Landin-Wilhelmsen K. Hypothyroidism is common in turner syndrome: results of a five-year followup. J Clin Endocrinol Metab 2005;90:2131-5.

10. Improda $N$, Rezzuto M, Alfano $S$, Parenti G, Vajro P, Pignata C, et al. Precocious puberty in Turner Syndrome: report of a case and review of the literature. Ital J Pediatr 2012;38:54.

11. Sabin MA, Zacharin MR. Precocious puberty in Turner syndrome. J Paediatr Child Health 2007;43:776-8.

12. Baek JU, Park HK, Shim EJ, Hwang IT. Precocious puberty in Turner syndrome variant. J Pediatr Adolesc Gynecol 2012;25:e113-4.

13. Evanchec KA, Rotenstein D. Treatment of precocious puberty in two patients with Turner mosaicism. J Pediatr Endocrinol Metab 2005;18:819-22.

14. Huseman CA. Mosaic Turner syndrome with precocious puberty. J Pediatr 1983;102:892-4.

15. Prueitt RL, Ross JL, Zinn AR. Physical mapping of nine Xq translocation breakpoints and identification of XPNPEP2 as a premature ovarian failure candidate gene. Cytogenet Cell Genet 2000;89:44-50.

16. Cho SY, Ki CS, Jang JH, Sohn YB, Park SW, Kim SH, et al. Familial Xp22.33-Xp22.12 deletion delineated by chromosomal microarray analysis causes proportionate short stature. Am J Med Genet A 2012;158A:1462-6.

17. Simpson JL, Rajkovic A. Ovarian differentiation and gonadal failure. Am J Med Genet 1999;89:186-200. 